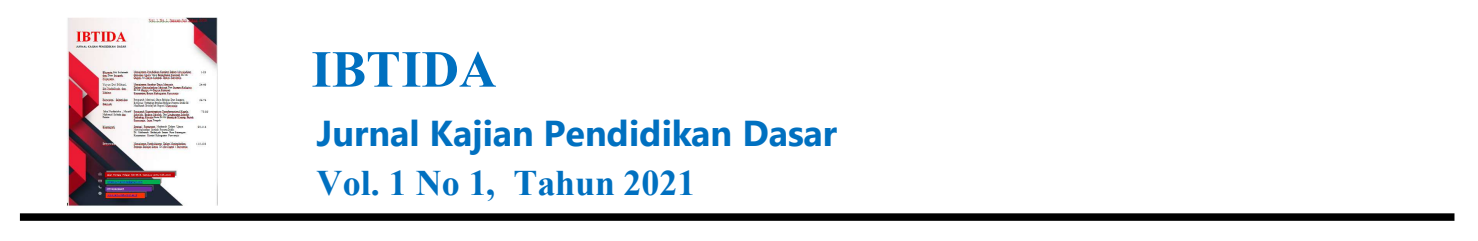

\title{
STRATEGI PEMASARAN MADRASAH DALAM UPAYA MENINGKATKAN JUMLAH PESERTA DIDIK DI MADRASAH IBTIDAIYAH IMAM PURO SUTORAGAN KECAMATAN KEMIRI KABUPATEN PURWOREJO
}

\author{
Kismiyati \\ (MI Roudlotul Huda Kutoarjo) \\ kismiyati651@,gmail.com
}

\begin{abstract}
ABSTRAK
Mengkaji strategi pemasaran madrasah di Madrasah Ibtidaiyah Imam Puro Sutoragan Kecamatan Kemiri Kabupaten Purworejo. Madrasah Ibtidaiyah Imam Puro Sutoragan Kecamatan Kemiri Kabupaten Purworejo merupakan salah satu dari lembaga pendidikan formal yang bertujuan untuk mencerdaskan anak bangsa. Terletak di desa yang jauh dari akses umum, tetapi mampu bersaing dengan lembaga pendidikan dasar lain. Madrasah Ibtidaiyah Imam Puro Sutoragan Kecamatan Kemiri Kabupaten Purworejo mulai tahun 2015 sampai dengan tahun 2019, mengalami peningkatan jumlah peserta didik secara terus menerus, sering memperoleh kejuaraan lomba, dan mampu meningkatkan saran prasarana pendidikan. Rumusan masalah pada penelitian ini adalah segmentation pemasaran madrasah, targetting pemasaran madrasah, dan positioning pemasaran madrasah di Madrasah Ibtidaiyah Imam Puro Sutoragan Kecamatan Kemiri Kabupaten Purworejo. Tujuan penelitian ini adalah untuk mengetahui segmentation pemasaran madrasah, targeting pemasaran madrasah, dan positioning pemasaran madrasah di Madrasah Ibtidaiyah Imam Puro Sutoragan Kecamatan Kemiri Kabupaten Purworejo. Jenis penelitian yang digunakan adalah penelitian kualitatif dengan hasil data akhir yang berupa uraian deskriptif. Teknik pengumpulan data menggunakan wawancara, observasi, dan dokumentasi. Adapun uji keabsahan data dilakukan dengan teknik triangulasi. Hasil penelitian ini adalah Strategi Pemasaran Madrasah di Madrasah Ibtidaiyah Imam Puro Sutoragan Kecamatan Kemiri Kabupaten Purworejo, terdiri dari: (1) Segmentasi pemasaran madrasah di MI Imam Puro Sutoragan Kecamatan Kemiri Kabupaten Purworejo yang meliputi: mengidentifikasi pasar, menentukan kebijakan segmentasi pasar, menetapkan tujuan segmentasi pasar, dan menentukan prosedur segmentasi pasar; (2) Targetting pemasaran madrasah di MI Imam Puro Sutoragan Kecamatan Kemiri Kabupaten Purworejo yang meliputi: memilih segmentasi pasar yang akan menjadi target pemasaran, menentukan strategi targeting pemasaran, dan melaksanakan strategi targetting pemasaran; dan (3) Positioning pemasaran madrasah di MI Imam Puro Sutoragan Kecamatan Kemiri Kabupaten Purworejo yang meliputi menentukan strategi positioning, mengimplementasikan strategi dan mengevaluasi strategi
\end{abstract}


positioning. Strategi pemasaran madrasah di Madrasah Ibtidaiyah Imam Puro Sutoragan Kecamatan Kemiri Kabupaten Purworejo sudah dilaksanakan dengan baik, dan berhasil diterima dengan baik di benak pelanggan.

Kata Kunci: Strategi, Pemasaran, Madrasah, Jumlah Peserta Didik.

\section{PENDAHULUAN}

Pada saat ini, dunia pendidikan sudah memasuki iklim kompetisi. Banyak lembaga pendidikan yang ditinggalkan pelanggannya sehingga mengalami dinamika negatif. Setiap lembaga pendidikan harus berbenah diri dengan menyesuaikan diri untuk memenuhi tuntutan konsumen atau pengguna lembaga pendidikan, agar keberadaannya tetap eksis.

Pemasaran lembaga pendidikan mutlak diperlukan. Lembaga pendidikan yang dimaksud adalah madrasah. Madrasah merupakan lembaga pendidikan Islam yang produknya adalah jasa pendidikan Islam. ${ }^{1}$

Untuk mempertahankan eksistensinya madrasah dituntut untuk melakukan pemasaran madrasah. Hal ini disebabkan adanya fenomena kecenderungan masyarakat yang lebih banyak berorientasi pada lembaga sekolah, dan pandangan pesimistis terhadap pendidikan madrasah berakibat kepada image bahwa madrasah adalah lembaga pendidikan kelas nomor dua. Dari survai sederhana yang dilakukan menunjukkan bahwa tingkat favorit madrasah di bawah lembaga sekolah. Selain itu, ternyata anggota masyarakat yang belum mengenal madrasah masih banyak. Fenomena tersebut mendorong madrasah harus melakukan upaya-upaya sosialisasi dan berusaha terus untuk meningkatkan kualitasnya, sehingga mempunyai daya saing tinggi dan dipercaya oleh masyarakat. ${ }^{2}$

Madrasah yang sudah mengimplementasi setrategi pemasaran madrasah dengan baik akan mengalami perkembangan setiap tahun, dimana salah satu indikatornya adalah semakin meningkat jumlah peserta didik. Sedangkan madrasah yang tidak melakukan upaya pemasaran, jumlah siswanya cenderung menurun dari tahun ke tahun, sehingga dapat terancam regrouping, bahkan gulung tikar.

\footnotetext{
1 Machali, Imam dan Hidayat, Ara. The Hand Book of Education Management, Teori dan Praktik Pengelolaan Sekolah/ Madrasah di Indonesia. (Jakarta: Prenadamedia Group, 2016), hlm. 289.

${ }^{2}$ lbid.
} 
Konsep dasar yang melandasi pemasaran adalah kebutuhan manusia. Kebutuhan manusia yaitu pernyataan dari rasa hilang, dan manusia mempunyai banyak kebutuhan yang kompleks. Kebutuhan kompleks tersebut meliputi kebutuhan fisik (makan, pakaian, perumahan), dan kebutuhan non fisik (rasa aman, aktualisasi, sosialisasi, penghargaan, dan kepemilikan). Semua kebutuhan berasal dari konsumen. Bila konsumen tidak puas, maka konsumen akan mencari produk atau jasa yang dapat memuaskan kebutuhan mereka.

Hal senada disampaikan Annarofiq, Kepala MI Imam Puro Sutoragan Kemiri bahwa masyarakat cenderung memilih lembaga pendidikan yang bisa memberikan layanan akademik yang terbaik kepada anak didik, antara lain: mutu lulusan yang baik yang dapat diterima di madrasah-madrasah unggulan, dan berhasil mendapatkan kejuaraan diberbagai pertandingan atau perlombaan.

Bagi masyarakat yang beragama Islam lebih mengharapkan keunggulan dalam bidang akhlak mulia, disamping keunggulan dalam bidang akademik. Mayoritas masyarakat yang beragama Islam, mendambakan putra putrinya mendapat pendidikan agama yang memadai, sehingga menjadi anak yang sholeh atau sholehah yang berbakti kepada orang tua, berguna bagi masyarakat dan lingkungannya, yang diharapkan menjadi investasi dunia akherat.

Harapan masyarakat terhadap madrasah yang berbasis religi ini tentunya harus diimbangi dengan kualitas madrasah. Madrasah harus berupaya meningkatkan sarana prasarana fasilitas belajar, memiliki program unggulan yang bersifat Islami sebagai diferensiasi atau pembeda dengan madrasah atau sekolah yang lain. Apabila memungkinkan madrasah perlu menekan biaya pendidikan yang yang berasala dari wali murid atau pelanggan pendidikan. Kemampuan seorang kepala madrasah dalam menentukan strategi pemasaran madrasah merupakan kunci dalam mempertahankan dan mengembangkan madrasah yang dikelolanya.

Persaingan antara sekolah umum dan madrasah di tingkat pendidikan dasar sudah mulai terasa pada tahun 2013/2014, pihak sekolah dasar mulai melakukan intervensi kepada lembaga Taman Kanak-Kanak (TK) untuk mengarahkan anak didiknya 
melanjutkan pendidikan ke sekolah dasar setempat, sehingga MI Imam Puro Sutoragan Kemiri membidik konsumen dari luar desa dengan berbagai cara. ${ }^{3}$

Madrasah pada dasarnya memiliki potensi yang besar dan dapat berkembang seperti sekolah umum lainnya. Selain keunggulan kurikulum Agama Islam yang lebih mendalam dibanding sekolah umum, juga adanya pengakuan Pemerintah dalam hal ini Kementerian Agama dan Pemerintah Daerah setempat. Namun saat ini pencitraan madrasah yang dipandang sebagai sekolah nomor dua menjadi tantangan ditengah persaingan global yang semakin ketat. Seiring kondisi ini berjalan muncul trend baru yang mencoba mengintegrasikan sekolah umum dengan muatan agama Islam di berbagai daerah, misalnya: Taman Kanak-Kanak Islam Terpadu (TK IT), Sekolah Dasar Islam Terpadu (SD IT), dan Sekolah Menengah Pertama Islam Terpadu (SMP IT). Berdirinya lembaga-lembaga pendidikan Taman Kanak-Kanak Islam Terpadu (TK IT), Sekolah Dasar Islam Terpadu (SD IT), dan Sekolah Menengah Pertama Islam Terpadu (SMP IT) berhasil menarik perhatian dan mendapat kepercayaan para konsumen jasa pendidikan karena lembaga-lembaga pendidikan tersebut dinilai mampu menciptakan citra (image) positif yang memuaskan. Hal ini membuat keberadaan lembaga pendidikan madrasah semakin tersaingi. Terbukti adanya Madrasah Ibtidaiyah yang jumlah siswanya dari tahun ke tahun terus mengalami penurunan yang signifikan, hal ini menurut penulis karena minimnya gerakan (action) dari pihak pengelola pendidikan madrasah untuk melakukan kegiatan pemasaran madrasah.

Berdasarkan survei dan wawancara penulis pada tanggal 7 September 2018 di Madrasah Ibtidaiyah Imam Puro Sutoragan Kecamatan Kemiri Kabupaten Purworejo, Bapak H. Muhammad Annarofiq, S.Pd.I., M.Pd. mengungkapkan bahwa promosi madrasah sangat penting dilakukan, karena dengan hal tersebut madrasah akan semakin dikenal oleh masyarakat. Keunggulan Madrasah Ibtidaiyah Imam Puro Sutoragan Kecamatan Kemiri Kabupaten Purworejo dalam menjalin kerjasama dengan warga masyarakat lingkungan sekitar, badan-badan usaha, dan lembaga-lembaga terkait, antara lain Raudlotul Athfal (RA) dan Taman Kanak-Kanak (TK) di Desa Sutoragan dan sekitarnya, Rumah Tahfid Wildan Mukhaladun untuk bekerja sama dalam mengajarkan hafalan Al-Qur'an, Pemerintahan Desa Sutoragan, Takmir Masjid, Pondok Pesantren,

\footnotetext{
${ }^{3}$ Wawancara dengan Kepala MI Imam Puro Sutoragan Kemiri Purworejo pada Hari Jum'at, Tanggal 7 September 2019.
} 
Puskesmas Unit Pelaksana Teknis (UPT) Kecamatan Kemiri untuk bekerja sama dalam bidang pemeriksaan kesehatan maupun sosialisasi masalah kesehatan kepada siswa, Kepolisian Sektor Kecamatan Kemiri untuk bekerja sama melatih ekstrakurikuler Polisi Kecil (POCIL), lembaga-lembaga lain untuk bekerja sama mengisi pembelajaran langsung di kelas inklusi, dan lembaga-lembaga bisnis untuk bekerjasama dalam bidang financial. $^{4}$

Pelaksanaan pembiasaan-pembiasaan keagamaan yang berciri khas Ahlu Sunnah Wal Jamaah antara lain: mengaji dengan para ustad/ustadzah Desa Sutoragan sebelum kegiatan pembelajaran, hafalan Al-Qur'an pada waktu istirahat oleh siswa-siswi Madrasah Ibtidaiyah Imam Puro Sutoragan Kecamatan Kemiri Kabupaten Purworejo yang belajar tahfidh di Rumah Tahfidh Wildan Mukhaladun. Anak-anak menghafalkan Al-Qur'an secara bergiliran dengan menggunakan pengeras suara, dengan tujuan untuk melatih anak-anak agar terbiasa berani tampil di depan umum menggunakan pengeras suara, sekaligus sebagai ajang promosi kepada warga masyarakat lingkungan sekitar. Selain itu kegiatan-kegiatan pembiasaan shalat Dhuha dan shalat Dhuhur berjamaah di masjid. Kegiatan ziarah dan tahlil di makam pendiri madrasah pada setiap Jum'at Kliwon. Pada setiap bulan Sya'ban menjelang Ramadhan siswa, guru, dan wali murid melakukan ziarah ke makam pendiri Madrasah Ibtidaiyah Imam Puro Sutoragan Kecamatan Kemiri Kabupaten Purworejo dan ke makam-makam para ulama di wilayah Kabupaten Purworejo.

Lebih lanjut keunggulan Madrasah Ibtidaiyah Imam Puro Sutoragan Kecamatan Kemiri Kabupaten Purworejo, baik akademik maupun non akademik, ketersediaan guru yang profesional, fasilitas sarana prasarana yang selalu ditingkatkan dan pelaksanaan program unggulan Madrasah Ibtidaiyah Imam Puro Sutoragan Kecamatan Kemiri Kabupaten Purworejo disosialisasikan secara langsung kepada wali murid sebagai laporan dan wali murid Raudhatul Athfal (RA) atau Taman Kanak-Kanak (TK) di lingkungan Desa Sutoragan dan sekitarnya sebagai salah satu upaya promosi. Selain penyampaian informasi secara langsung juga ditempuh penyampaian informasi melalui media sosial.

\footnotetext{
${ }^{4}$ Ibid.
} 
Hal yang sangat menarik bagi penulis untuk mengetahui sejauh mana implementasi strategi pemasaran madrasah di Madrasah Ibtidaiyah Imam Puro Sutoragan Kecamatan Kemiri Kabupaten Purworejo yang berhasil dalam kegiatan Penerimaan Peserta Didik Baru (PPDB), bahkan sampai menolak siswa karena kapasitas ruang kelas yang masih terbatas pada Tahun Pelajaran 2018/2019.

Berdasarkan permasalahan tersebut diatas penulis ingin mencoba melakukan kajian mengenai strategi pemasaran madrasah di Madrasah Ibtidaiyah Imam Puro Sutoragan Kecamatan Kemiri Kabupaten Purworejo, dengan alasan madrasah tersebut merupakan lembaga pendidikan madrasah ibtidaiyah swasta yang berada di lingkungan pedesaan, dan jauh dari akses lalu lintas umum tetapi berhasil dalam kualitas dan kuantitas. Keberhasilan dalam kualitas dapat dilihat dari lulusan Madrasah Ibtidaiyah Imam Puro Sutoragan Kecamatan Kemiri Kabupaten Purworejo yang dapat diterima diperbagai sekolah unggulan. Selain itu Madrasah Ibtidaiyah Imam Puro Sutoragan Kecamatan Kemiri Kabupaten Purworejo dapat meraih kejuaraan dari berbagai lomba. Ketrampilan siswa-siswi Madrasah Ibtidaiyah Imam Puro Sutoragan Kecamatan Kemiri Kabupaten Purworejo sering ditampilkan dalam acara-acara kedinasan, kemasyarakatan, dan kegiatan akhirus sanah. Antara lain penampilan kegesitan Polisi Kecil (POCIL) pada upacara-upacara kedinasan di tingkat Kecamatan maupun Kabupaten, hafalan AlQur'an pada acara-acara kemasyarakatan, penampilan drum band pada acara pawai peserta khataman Al-Qur'an, paduan suara pada kegiatan-kegiatan di desa, dan lain sebagainya. Madrasah Ibtidaiyah Imam Puro Sutoragan Kecamatan Kemiri Kabupaten Purworejo berhasil menarik antusias berbagai lapisan masyarakat untuk mendukung peningkatan fasilitas sarana prasaran pembelajaran dengan memberi sumbangan dana, juga wakaf tanah (donatur suka rela tidak mengikat). Keberhasilan dalam kuantitas dibuktikan dengan jumlah siswa Madrasah Ibtidaiyah Imam Puro Sutoragan Kecamatan Kemiri Kabupaten Purworejo yang meningkat dari tahun ke tahun, dan pada tahun pelajaran 2018/2019 sampai menolak siswa karena keterbatasan jumlah ruang kelas.

\section{KAJIAN LITERATUR}

\section{Strategi Pemasaran}

Menurut Philip Kotler, pada dasarnya strategi pemasaran ada tiga jenis strategi umum, yaitu: Pertama, strategi keunggulan biaya secara keseluruhan (cost leadership), strategi organisasi menjadi pemimpin biaya (cost leader), artinya 
kualitas produk relatif sama dengan pesaing, organisasi dapat memberikan harga yang jauh lebih murah sebagai strategi menarik pelanggan. Kedua, strategi diferensiasi (defferentiation), pada strategi ini organisasi berusaha untuk menghantarkan produk unik pada beberapa dimensi pelanggan. Ketiga, strategi fokus (focus), melalui strategi ini organisasi berusaha fokus pada segmen tertentu untuk kemudian dilayani dengan strategi keunggulan biaya atau diferensiasi. ${ }^{5}$

Menurut Sofjan Assauri, Strategi pemasaran pada dasarnya adalah rencana yang menyeluruh, terpadu, dan menyatu di bidang pemasaran, yang memberikan panduan tentang kegiatan yang akan dijalankan untuk dapat tercapainya tujuan pemasaran suatu perusahaan. Dengan kata lain strategi pemasaran adalah serangkaian tujuan dan sasaran, kebijakan dan aturan yang memberi arah pada usahausaha pemasaran perusahaan dari waktu ke waktu, pada masing-masing tingkatan dan acuan serta alokasinya, terutama sebagai tanggapan perusahaan dalam menghadapi lingkungan dan keadaan persaingan yang selalu berubah. ${ }^{6}$

Menurut Cannon, et al., bahwa Strategi pemasaran (marketing strategy) merupakan gambaran besar mengenai yang akan dilakukan oleh suatu perusahaan di suatu pasar. ${ }^{7}$ Tull dan Kahle (dalam Fandy Tjiptono), mendefinisikan strategi pemasaran sebagai alat fundamental yang direncanakan untuk mencapai tujuan perusahaan dengan mengembangkan keunggulan bersaing yang berkesinambungan melalui pasar yang dimasuki dan program pemasaran yang digunakan untuk melayani pasar sasaran tersebut. ${ }^{8}$ Pada dasarnya strategi pemasaran memberikan arah dalam kaitannya dengan variabel-variabel seperti segmentasi pasar, identifikasi pasar sasaran, positioning, elemen bauran pemasaran, dan biaya bauran pemasaran. Strategi pemasaran merupakan bagian integral dari strategi bisnis yang memberikan arah pada semua fungsi manajemen suatu organisasi.

\footnotetext{
${ }^{5}$ Kotler, Philip. Manajemen Pemasaran Edisi Milenium 1. (Jakarta: Prenhallindo, 2002), hlm. 92.

${ }^{6}$ Assauri, Sofjan. Manajemen Pemasaran, Dasar, Konsep dan Strategi. (Jakarta: Raja Grafindo Persada, 2017), hIm. 168.

${ }^{7}$ Cannon, Joseph P., et al. Pemasaran Dasar, Edisi 16 Pendekatan Manajerial Global Buku 1. (Jakarta: Salemba Empat, 2008), hlm. 40.

${ }^{8}$ Tjiptono, Fandy. Strategi Pemasaran Edisi III. (Yogyakarta: Andi Offset, 2008), hIm. 6.
} 
Corey (dalam Fandy Tjiptono), bahwa strategi pemasaran terdiri atas lima elemen yang saling berkaitan yaitu pemilihan pasar, perencanaan produk, penetapan harga, sistem distribusi dan komunikasi pemasaran. ${ }^{9}$ Bennett (dalam Fandy Tjiptono), bahwa Strategi pemasaran merupakan pernyataan (baik secara implisit maupun eksplisit) mengenai bagaimana suatu merek atau lini produk mencapai tujuannya. ${ }^{10}$ Freddy Rangkuti, bahwa perumusan strategi pemasaran didasarkan pada analisis yang menyeluruh terhadap pengaruh faktor-faktor lingkungan eksternal dan internal perusahaan. Lingkungan eksternal perusahaan setiap saat berubah dengan cepat sehingga melahirkan berbagai peluang dan ancaman baik yang datang dari pesaing utama maupun dari iklim bisnis yang senantiasa berubah. Konsekuensi perubahan faktor eksternal tersebut juga mengakibatkan perubahan faktor internal perusahaan, seperti perubahan terhadap kekuatan maupun kelemahan yang dimiliki perusahaan tersebut. ${ }^{11}$

Berdasarkan beberapa pendapat diatas dapat disimpulkan bahwa strategi pemasaran adalah serangkaian kebijakan dan aturan suatu perusahaan didasarkan pada analisis yang menyeluruh terhadap pengaruh faktor-faktor lingkungan eksternal dan internal yang akan dilakukan untuk memberi arah pada usaha-usaha pemasaran dalam kaitannya dengan variabel-variabel seperti segmentasi pasar, identifikasi pasar sasaran, positioning, elemen bauran pemasaran, dan biaya bauran pemasaran sebagai tanggapan perusahaan dalam menghadapi lingkungan dan keadaan persaingan yang selalu berubah.

\section{Strategi Pemasaran Madrasah}

Imam Machali dan Ara Hidayat, bahwa pemasaran jasa pendidikan memiliki karakteristik antara lain: (a) tidak berwujud (intangibel); (b) tidak terpisahkan (inseparability); (c) bervariasi (variability); (d) Mudah musnah (perishability); (e) jasa tidak dapat disimpan dan dikonsumsi pada saat dihasilkan; (f) konsumen merupakan bagian integral dari proses produksi jasa; (g) setiap orang apapun yang

\footnotetext{
9 Tjiptono, Fandy. Strategi Pemasaran, Promosi, Iklan, Media Sosial, Kompetitif Market, Distribusi, Pelanggan, Pasar, Branding, Produk, Harga Edisi-4. (Yogyakarta: Andi Offset, 2015), hlm. 17.

${ }^{10}$ Tjiptono, Fandy, 2008, Op.Cit.

${ }^{11}$ Rangkuti, Freddy. Teknik Membedah Kasus Bisnis Analisis Swot. (Jakarta: Gramedia Pustaka Utama, 2017), hlm. 101.
} 
berhubungan dengan konsumen mempunyai andil dalam memberikan peranan; (h) karyawan penghubung merupakan bagian dari proses jasa; dan (i) kualitas jasa tidak dapat diperbaiki pada saat proses produksi karena produksi jasa terjadi secara real time. $^{12}$

Kotler dan Fox (dalam David Wijaya), mengatakan definisi pemasaran yang digunakan secara khusus pada sekolah sebagai analisis perencanaan, pelaksanaan, dan pengendalian program yang dirumuskan secara hati-hati, yang dirancang untuk menghasilkan pertukaran nilai secara sukarela dengan pasar sasaran/pasar target (target market) jasa pendidikan untuk mencapai tujuan sekolah. ${ }^{13}$

Kriegbahum (dalam Muhaimin et al.), mengemukakan bahwa pemasaran pada lembaga sekolah/madrasah didefinisikan sebagai pengolahan yang sistematis dari pertukaran nilai-nilai yang sengaja dilakukan untuk mempromosikan misi-misi sekolah/madrasah berdasarkan pemuasan kebutuhan nyata baik itu untuk stakeholder ataupun masyarakat sosial pada umumnya. ${ }^{14}$

Pemasaran madrasah adalah kegiatan lembaga pendidikan dalam memberikan layanan atau menyampaikan jasa pendidikan kepada konsumen dengan cara yang memuaskan. Seperti kita ketahui bahwa lembaga pendidikan adalah sebuah kegiatan yang melayani konsumen, berupa siswa, mahasiswa, masyarakat umum yang dikenal sebagai stakeholder. Lembaga pendidikan hakekatnya untuk memberikan layanan, dan pihak yang dilayani ingin mendapatkan kepuasan, karena mereka sudah membayar cukup kepada lembaga pendidikan. ${ }^{15}$

Berdasarkan beberapa pendapat diatas dapat disimpulkan bahwa strategi pemasaran madrasah adalah serangkaian kebijakan suatu madrasah yang akan dilakukan untuk memberi arah pada usaha-usaha dalam memberikan layanan atau menyampaikan jasa pendidikan yang memuaskan kepada pelanggan dan masyarakat

\footnotetext{
12 Machali, Imam dan Hidayat, Ara, Op.Cit., hlm. 282-283.

${ }^{13}$ Wijaya, David. Pemasaran Jasa Pendidikan. (Jakarta: Bumi Aksara, 2016), hlm. 21.

14 Muhaimin et al., Manajemen Pendidikan Aplikasi dalam Penyusunan Rencana Pengembangan Sekolah/Madrasah. (Jakarta: Prenadamedia Group, 2015), hlm. 97-98.

${ }^{15}$ Alma, Buchari. Manajemen Pemasaran dan Pemasaran Jasa. (Bandung: Alfabeta, 2016), hlm. 45.
} 
secara terus menerus dan berkesinambungan sebagai upaya mencapai tujuan madrasah dengan sumber daya yang dimiliki.

\section{Penerimaan Peserta Didik Baru}

Peserta didik juga disebut anak didik atau terdidik atau siswa, mahasiswa, taruna, warga belajar, pelajar, murid, santri, yaitu orang yang mencari dan menerima ilmu dari pendidik. ${ }^{16}$ Peserta didik merupakan subyek dimana semua aktifitas yang dilakukan di lembaga pendidikan (sekolah) pada akhirnya bermuara. ${ }^{17}$ Peserta didik adalah setiap orang yang menerima pengaruh dari seseorang atau sekelompok orang yang menjalankan kegiatan pendidikan. Peserta didik merupakan objek dan sekaligus subjek pendidikan. ${ }^{18}$

Menurut Suharsimi Arikunto dan Lia Yuliana, penerimaan siswa baru merupakan peristiwa penting bagi sekolah, karena peristiwa ini merupakan titik awal yang menentukan kelancaran tugas sesuatu sekolah. ${ }^{19}$ Kesalahan dalam penerimaan siswa baru dapat menentukan sukses tidaknya usaha pendidikan di sekolah yang bersangkutan.

Menurut Suharsimi Arikunto dan Lia Yuliana, tugas panitia penerimaan siswa baru adalah: (a) Menentukan banyaknya siswa yang diterima. (b) Menentukan syaratsyarat penerimaan siswa baru. (c) Melaksanakan penyaringan. Penyaringan siswa baru didasarkan atas pertimbangan target, dan pertimbangan nilai atau tingkat kemampuan yang telah titetapkan. (d) Mengadakan pengumuman penerimaan. (e) Mendaftar kembali calon yang sudah diterima. (f) Melaporkan hasil pekerjaannya kepada pimpinan sekolah, sebagai wujud tanggung jawab setelah melaksanakan pekerjaan. $^{20}$

\footnotetext{
${ }^{16}$ Eliyanto. Manajemen \& Kepemimpinan Pendidikan Islam. (Kebumen: Institut Agama Islam Nahdlatul Ulama (IAINU), 2018), hlm. 130.

${ }^{17}$ Farikhah, Siti. Manajemen Lembaga Pendidikan. (Yogyakarta: Aswaja Presindo, 2015), hlm. 37.

${ }^{18}$ Machali, Imam dan Hidayat, Ara, Op.Cit., hlm. 45.

${ }^{19}$ Arikunto, Suharsimi dan Yuliana, Lia. Manajemen Pendidikan. (Yogyakarta: Aditya Media bekerja sama dengan FIP UNY, 2012), hlm. 32.

${ }^{20} \mathrm{Ibid}, \mathrm{hlm} .32-34$.
} 
Sedangkan menurut Jaja Jahari dan Amirulloh Syarbini, bahwa manajemen peserta didik mencakup seluruh proses dalam pengelolaan peserta didik semenjak analisis kebutuhan sampai peserta didik tersebut menjadi alumni, meliputi: (a) analisis kebutuhan; (b) rekruitmen; (c) seleksi dan penerimaan; (d) proses pencatatan dan pelaporan; (e) orientasi; (f) penempatan; (g) pembinaan dan pengajaran, kelulusan dan alumni. ${ }^{21}$

Dari beberapa pendapat diatas dapat disimpulkan bahwa penerimaan siswa baru adalah kegiatan yang mengintegrasikan berbagai tujuan (goals), berbagai kebijakan (policies), dan berbagai tindakan (program), dalam upaya mencari dan menentukan calon siswa baru yang biasanya dilakukan menjelang tahun pelajaran baru samapai memperoleh siswa baru yang sesuai dengan daya tampung/ ruang kelas yang tersedia dan tenaga pendidik maupun tenaga kependidikan yang ada dalam sebuah lembaga pendidikan.

Adapun langkah-langkah dalam penerimaan siswa baru antara lain: (a) menentukan banyaknya siswa yang diterima; (b) menentukan syarat-syarat penerimaan siswa baru; (c) melaksanakan penyaringan; (d) mengadakan pengumuman penerimaan; (e) mendaftar kembali calon yang sudah diterima; dan (f) melaporkan hasil pekerjaannya kepada pimpinan sekolah.

\section{METODE PENELITIAN}

Jenis penelitian ini yaitu kualitatif, pendekatan yang lebih menekankan pada aspek pemahaman secara mendalam terhadap suatu masalah manusia dan sosial. Waktu penelitian adalah antara bulan April 2019 sampai dengan Juli 2019, dan tempat penelitian adalah di MI Imam Puro Sutoragan Kec. Kemiri, Kab. Purworejo.

Subjek dan informan penelitian ini yaitu orang-orang yang berhubungan dengan strategi pemasaran madrasah dalam upaya meningkatkan jumlah peserta didik, yaitu: kepala madrasah, guru, karyawan, orang tua peserta didik, peserta didik MI Imam Puro Sutoragan Kec. Kemiri, Kab. Purworejo.

\footnotetext{
${ }^{21}$ Jahari, Jaja dan Syarbini, Amirulloh Syarbini. Manajemen Madrasah Teori, Strategi dan Implementasi. (Bandung: Alfabeta, 2013), hlm. 20-24.
} 
Teknik pengumpulan data merupakan cara yang digunakan peneliti untuk memperoleh data penelitian yang dibutuhkan. Proses pengumpulan data dalam penelitian ini dilakukan dengan: observasi, wawancara mendalam, dan dokumentasi.

Dalam menguji keabsahan data peneliti menggunakan tehnik Triangulasi, yakni teknik pemeriksaan keabsahan data yang memanfaatkan sesuatu yang lain diluar data untuk keperluan pengecekan atau sebagai pembanding terhadap data itu. Itu artinya melakukan validasi, dengan cara mengecek dokumen program dan bukti tertulis lainnya. ${ }^{22}$ Dalam penelitian ini menggunakan Triangulasi metode yaitu menggunakan dua strategi yaitu: (1) Pengecekan terhadap derajat kepercayaan penemuan hasil penelitian dengan beberapa tehnik pengumpulan data; (2) Pengecekan derajat kepercayaan beberapa sumber data dengan metode yang sama.

Langkah-langkah yang dilakukan penulis lakukan untuk menganalisis data yang sudah diperoleh dari hasil observasi, wawancara, dan dokumentasi yaitu dengan menggunakan model analisis data Miles dan Huberman sebagaimana yang dikutip oleh Sugiyono, yaitu reduksi data (data reduction), penyajian data (data display), dan penarikan kesimpulan (conclusion drawing/verification) ${ }^{23}$

\section{HASIL PENELITIAN DAN PEMBAHASAN}

1. Segmentation Pemasaran Madrasah di Madrasah Ibtidaiyah (MI) Imam Puro Sutoragan Kecamatan Kemiri Kabupaten Purworejo

Segmentasi pasar merupakan salah satu unsur yang pertama dalam strategi persaingan pemasaran. Segmentasi pasar yaitu tindakan menngidentifikasi dan membentuk kelompok pembeli atau konsumen secara terpisah. Masing-masing konsumen ini memiliki karakteristik, kebutuhan produk, dan bauran pemasaran sendiri. ${ }^{24}$ Segmentasi pemasaran madrasah di Madrasah Ibtidaiyah Imam Puro Sutoragan Kecamatan Kemiri Kabupaten Purworejo sebagai berikut:

\section{a. Mengidentifikasi pasar}

Sebelum membagi-bagi pasar pada segmen-segmen tertentu, riset pasar (market research) biasanya dilakukan terlebih dahulu. Dengan demikian,

\footnotetext{
${ }^{22}$ Patton, Michael Quinn. Metode Evaluasi Kualitatif. (Yogyakarta: Pustaka Pelajar, 2006), hal. 280.

${ }^{23}$ Sugiyono, Metode Penelitian Pendidikan, (Bandung: Alfabeta. 2009), hal. 254.

${ }^{24}$ Machali, Imam dan Hidayat, Ara, Op.Cit., hlm. 278.
} 
segmen-segmen tertentu diharapkan dapat diketahui, kebutuhan dan keinginannya dapat dipenuhi produsen/perusahaan. ${ }^{25}$

Berdasarkan hasil penelitian bahwa proses identifikasi pasar Madrasah Ibtidaiyah (MI) Imam Puro Sutoragan Kecamatan Kemiri Kabupaten Purworejo yaitu dengan melakukan penelitian sederhana kepada calon orang tua peserta didik untuk mengetahui keinginan calon orang tua peserta didik tentang pendidikan anaknya. Adapun cara yang ditempuh bersilaturahmi kepada tokoh masyarakat dan bergabung dalam kegiatan-kegiatan keagamaan dan sosial masyarakat. Melalui cara tersebut, petugas riset dapat menyerap aspirasi juga dapat melakukan wawancara terselubung untuk mengetahui keinginan orang tua calon peserta didik. Sedangkan penelitian terhadap lembaga pendidikan kompetitor yaitu sekolah yang berada di sekitarnya dengan cara aktif mengikuti kegiatan Kelompok Kerja Kepala (KKK SD/MI) dan Kelompok Kerja Guru (KKG) yang diadakan oleh Pelayanan Pendidikan Kecamatan (PPK) Kemiri. Selain itu juga aktif mengikuti kegiatan Kelompok Kerja Kepala Madrasah Ibtidaiyah (KKK MI) dan Kelompok Kerja Guru Madrasah Ibtidaiyah (KKG MI) yang diadakan oleh Kementerian Agama Kabupaten Purworejo. Melalui kegiatan ini pengelola Madrasah Ibtidaiyah Sutoragan Kecamatan Kemiri Kabupaten Purworejo dapat mengetahui keadaan Sekolah Dasar (SD) dan Madrasah Ibtidaiyah (MI) yang ada di sekitarnya, antara lain mutu lulusan, Sumber Daya Tenaga Pendidik, keadaan sarana prasarana, program unggulan, pembiayaan, dan sebagainya. Untuk menambah ilmu dan wawasan Kepala Madrasah dan Dewan Guru Madrasah Ibtidaiyah Imam Puro Sutoragan Kecamatan Kemiri Kabupaten Purworejo melakukan study banding ke sekolah yang lebih maju yaitu Madrasah Ibtidaiyah Negeri (MIN) Njejeran Bantul.

\section{b. Menentukan kebijakan segmentasi pasar}

Berdasarkan hasil penelitian, Madrasah Ibtidaiyah (MI) Imam Puro Sutaragan Kecamatan Kemiri Kabupaten Purworejo menentukan kebijakan segmentasi pasar kepada calon orang tua peserta didik berdasarkan geografis, demografis, dan perilaku. Sedangkan secara demografis Madrasah Ibtidaiyah

25 Lumpioadi, Rambat. Manajemen Pemasaran Jasa Berbasis Kompetensi. (Jakarta: Salemba Empat, 2013), hlm. 54. 
Imam Puro Sutoragan Kecamatan Kemiri Kabupaten Purworejo menentukan calon orang tua peserta dididk berdasar agama, umur anak, pendidikan anak, perilaku anak, dan perilaku orang tua. Penentuan kebijakan segmentasi tersebut untuk menentukan calon orang tua peserta didik yang akan dibidik menjadi target pemasaran. Calon peserta didik yang akan dibidik menjadi target pemasaran oleh Madrasah Ibtidaiyah (MI) Imam Puro Sutoragan Kecamatan Kemiri Kabupaten Purworejo, adalah calon peserta didik yang berasal dari Desa Sutoragan dan sekitarnya, beragama Islam, berumur antara 6-7 tahun, anak yang normal bukan anak yang berkebutuhan khusus (ABK), yang orang tuanya memiliki komitmen tinggi untuk menyekolahkan anak-anaknya di Madrasah Ibtidaiyah (MI) Imam Puro Sutoragan Kecamatan Kemiri Kabupaten Purworejo agar anaknya mendapatkan ilmu Ibtidaiyah Imam Puro Sutoragan Kecamatan Kemiri Kabupaten Purworejo agar anaknya mendapatkan ilmu agama Islam yang memadai, terbiasa mengamalkan ajaran Agama Islam berhaluan Ahlussunah Wal Jamaah, terbiasa mengamalkan karakter akhlak mulia dan mendapatkan ilmu pengetahuan umum yang setara dengan sekolah dasar pada umumnya sehingga menjadi generasi hebat dan bermartabat, berpikiran maju, siap dalam menghadapai masa depan, bertaqwa kepada Allah Swt, berperilaku yang santun, dan berkepribadian mencintai Al-Qur'an.

\section{c. Menetapkan tujuan segmentasi pasar}

Tujuan utama dalam segmentasi pasar, yaitu untuk melayani konsumen secara lebih baik dan memperbaiki posisi daya saing atau kompetitif perusahaan terhadap kompetitor. Sedangkan tujuan yang lebih sempit seperti meningkatkan penjualan, meningkatkan pangsa pasar, melakukan komunikasi dan promosi, dan memperkuat citra. ${ }^{26}$

Berdasarkan hasil pengamatan, Madrasah Ibtidaiyah (MI) Imam Puro Sutoragan sudah menetapkan tujuan segmentasi pasar yaitu agar dapat melayani pelanggan dengan baik, mendapatkan peluang, dan meningkatkan posisi daya saing terhadap lembaga pendidikan kompetitornya.

26 Ibid. 
1) Indikator tujuan agar dapat melayani pelanggan dengan baik yaitu upaya Madrasah Ibtidaiyah Imam Puro Sutoragan membuat berbagai program strategis dalam pembiasan karakter akhlak mulia, pembiasaan pengamalan Islam berciri khas Ahlussunah Wal Jamaah, berbagai kegiatan ekstrakurikuler, selalu meningkatkan sarana prasana pendidikan, keunggulan biaya dan sebagainya merupakan indikator dalam melayani pelanggan dengan baik, karena diantara motivasi orang tua peserta didik menyekolahkan putra putrinya di Madrasah Ibtidaiyah (MI) Imam Puro Sutoragan untuk mendapat pendidikan agama yang memadai dan ilmu pengetahuan umum yang setara dengan lembaga pendidikan dasar umum lainnya.

2) Indikator tujuan agar mendapatkan peluang yaitu keberhasilan peserta didik Madrasah Ibtidaiyah (MI) Imam Puro Sutoragan tampil dalam berbagai kesempatan antara lain penampilan POCIL pada upacara hari Proklamasi di Kecamatan Kemiri, penampilan drum band pada acara-acara arak-arakan peringatan hari besar Islam, adanya tenaga-tenaga profesi yang berkenan mengisi kegiatan kelas inspirasi, dan mengalirnya berbagai donatur yang membantu pembangunan dan kelengkapan sarana prasarana kegiatan belajar mengajar.

3) Indikator meningkatkan posisi daya saing terhadap lembaga pendidikan kompetitornya antara lain dapat dilihat dari meningkatnya jumlah peserta didik dari tahun ke tahun. Selain itu diperolehnya Prestasi akademik dan non akademik.

\section{d. Menentukan prosedur segmentasi pasar}

Prosedur segmentasi pasar ada tiga langkah, yaitu: (1) survei untuk mendapatkan pemahaman atas motivasi, sikap, dan perilaku konsumen; (2) analisis untuk membuang variabel-variabel yang berkorelasi tinggi kemudian menerapkan analisis kelompok sehingga menghasilkan jumlah segmen yang berbeda-beda secara maksimum; dan (3) pembentukan profil. Masing-masing kelompok dibentuk berdasarkan perbedaan sikap, perilaku, demografis, 
psikografis, dan pola media. Masing-masing segmen dapat diberi nama berdasarkan sifat-sifat dominannya. ${ }^{27}$

Berdasarkan pengamatan Madrasah Ibtidaiyah (MI) Imam Puro Sutoragan Kecamatan Kemiri Kabupaten Purworejo sudah melakukan prosedur segmentasi yang baik. Prosedur tersebut dimulai dengan identifikasi calon peserta didik berdasar tempat tinggal, agama, umur, pendidikan, perilaku anak, dan sikap dan perilaku calon orang tua peserta didik. Karakteristik tersebut dikelompokkan dan dianalisa untuk mendapatkan segmen yang dominan dan tepat.

\section{Targetting Pemasaran Madrasah di Madrasah Ibtidaiyah Imam Puro Sutoragan Kecamatan Kemiri Kabupaten Purworejo}

Unsur strategi persaingan pemasaran setelah segmentasi pasar yaitu targetting. Targetting yaitu tindakan memilih satu atau lebih segmen yang akan dimasuki. ${ }^{28}$

\section{a. Memilih segmen pasar yang akan menjadi target pemasaran}

Setelah pasar disegmentasi, maka sangatlah perlu untuk memilih segmen pasar tertentu yang menjadi fokus upaya pemasaran. Pembidikan pasar (market targetting) adalah spesifikasi sejumlah segmen pasar yang diambil oleh organisasi. Setelah manajer menetapkan pembidikan pasar, organisasi harus memutuskan strategi mana yang akan digunakan. ${ }^{29}$

Berdasarkan hasil penelitian Madrasah Ibtidaiyah Imam Puro Sutoragan Kecamatan Kemiri sudah memilih segmen pasar yang akan dibidik menjadi target pemasaran yaitu anak yang berdomisili di Desa Sutoragan dan sekitarnya, agama yaitu Islam, umur yaitu antara 6-7 tahun, pendidikan yaitu RA atau TK, anak yang normal yaitu bukan anak berkebutuhan khusus, dan calon orang tua peserta didik yang berkomitmen untuk menyekolahkan anaknya di Madrasah Ibtidaiyah agar mendapatkan pendidikan agama yang memadai dan pendidikan umum yang setara dengan sekolah dasar umum. Selain itu Madrasah Ibtidaiyah

\footnotetext{
${ }^{27}$ Laksana, Fajar. Manajemen Pemasaran Pendekatan Praktis. (Yogyakarta: Graha Ilmu, 2008), hlm. 3435.

${ }^{28}$ Machali, Imam dan Hidayat, Ara, Op.Cit.

29 Kerin, Roger A. dan Peterson, Robert A. Pemasaran Strategis, Kasus dan Komentar Edisi Bahasa Indonesia. (Jakarta: Indeks Permata Putri Media, 2015), hlm. 71.
} 
Imam Puro Sutoragan Kecamatan Kemiri mengutamakan calon peserta yang berasal dari RA Masithoh Sutoragan.

\section{b. Menentukan strategi targetting pemasaran}

Berdasarkan hasil penelitian, Madrasah Ibtidaiyah (MI) Imam Puro Sutoragan Kecamatan Kemiri Kabupaten Purworejo menerapkan strategi targetting terdiferensiasi, yaitu calon peserta didik yang berasal dari RA Masyithoh Sutoragan, dan calon peserta didik yang berasal dari selain RA Masyithoh Sutoragan. Untuk yang berasal dari RA Masyithoh Sutoragan, karakteristik peserta didik dan orang tua peserta didik sudah diseleksi oleh RA Masyithoh Sutoragan. Sedangkan yang berasal dari selain RA Masyithoh Sutoragan karakteristik berdomisili di Desa Sutoragan dan sekitarnya, beragama Islam, berpendidikan RA atau TK, berumur 6-7 tahun, anak yang normal bukan anak berkebutuhan khusus, dan orang tua calon peserta didik tersebut berkomitmen untuk menyekolahkan putra putrinya ke Madrasah Ibtidaiyah Imam Puro Sutoragan, diseleksi oleh MI Imam Puro Sutoragan Kecamatan Kemiri Kabupaten Purworejo

\section{c. Melaksanakan strategi targetting pemasaran}

Berdasarkan hasil penelitian, Madrasah Ibtidaiyah (MI) Imam Puro Sutoragan Kecamatan Kemiri Kabupaten Purworejo strategi targetting pemasaran, sangat memperhatikan banyaknya segmen yang akan dilayani dan layanan jasa pendidikan yang akan ditawarkan. Jasa yang ditawarkan oleh Madrasah Ibtidaiyah (MI) Imam Puro Sutoragan adalah Jasa Pendidikan Tingkat Dasar yang berciri khas Islam Ahlussunah Wal Jamaah. Adapun segmen pasar yang akan di layani adalah terbagi menjadi dua yang berasal dari RA Masyithoh Sutoragan dan dari RA atau TK selain RA Masyithoh Sutoragan. Pelaksanaan strategi targetting terhadap calon peserta didik yang berasal dari RA Masyithoh Sutoragan sudah terintegrasi dengan pelaksanaan kegiatan program strategis MI Imam Puro Sutoragan, antara lain dalam kegiatan Sabtu sehat tanpa jajan, kelas inspirasi, ziarah, mujahadah, silaturahim awal tahun pelajaran, upacara, peringatan hari besar Nasional, peringatan hari besar Islam, dan akhirussanah. Sedangkan pelaksanaan strategi targetting terhadap calon peserta didik yang berasal dari selain RA Masyitoh Sutoragan dilakukan 
melalui aktif dalam kegiatan sosial, silaturrahim, brosur, media sosial, dan dari mulut ke mulut.

\section{Positioning Pemasaran Madrasah di Madrasah Ibtidaiyah Imam Puro Sutoragan Kecamatan Kemiri Kabupaten Purworejo}

Puncak kegiatan strategi persaingan pemasaran adalah positioning. Positioning adalah penetapan posisi pasar. Tujuan positioning adalah membangun dan mengkomunikasikan keunggulan bersaing produk yang ada di pasar ke dalam benak konsumen. ${ }^{30}$

\section{a. Menentukan strategi positioning}

Strategi positioning didasarkan pada: (1) Atribut / manfaat produk. (2) Penggunaan atau aplikasi; (3) Produk atau merek pengguna; (4) Kelas produk atau jasa; (5) Memposisikan dirinya langsung terhadap pesaing; (6) kualitas. (Rajeev Batra dalam Roger A. Kerin dan Robert A. Peterson). ${ }^{31}$ Strategi positioning pemasaran lembaga pendidikan sangat menentukan tingkat keberhasilan dalam kegiatan positioning. Strategi positioning adalah cara yang ditentukan oleh pengelola lembaga pendidikan dalam mengkomunikasikan program unggulannya agar mendapat tempat yang baik di benak orang tua calon peserta didik.

Berdasarkan hasil penelitian, Madrasah Ibtidaiyah Imam Puro Sutoragan sudah menentukan strategi positioning pemasaran. Adapun kebijakan strategi posioning yang sudah ditentukan itu antara lain: (1) menawarkan diferensiasi layanan jasa; (2) menciptakan kepuasan pelanggan; (3) membangun loyalitas pelanggan; (4) mengintensifkan komunikasi dengan pelanggan; dan (5) meningkatkan sarana prasarana pendidikan.

\section{b. Mengimplementasikan strategi positioning}

Berdasarkan hasil penelitian, Madrasah Ibtidaiyah Imam Puro Sutoragan Kecamatan Kemiri Kabupaten Purworejo sudah mengimplementasikan strategi positioning yang sudah ditentukan yaitu: (1) Menawarkan diferensiasi layanan jasa kepada siswa. Antara lain melalui kegiatan: seragam siswa dengan atribut

\footnotetext{
${ }^{30}$ Machali, Imam dan Hidayat, Ara, Op.Cit.

${ }^{31}$ Kerin, Roger A. dan Peterson, Robert A., Op.Cit., hlm. 147.
} 
Lembaga Pendidikan Ma'arif Nahdlotul Ulama, pembiasaan pengamalan Islam berciri khas Ahlussunah Wal Jamaah, pembiasaan karakter akhlak mulia, memberikan penghargaan kepada siswa berprestasi, menyelenggarakan kegiatan ekstrakurikuler, dan keunggulan biaya; (2) Menciptakan kepuasan pelanggan, baik pelanggan intern maupun pelanggan ekstern. Cara yang diimplementasikan untuk memuaskan pelanggan intern yaitu kesempatan melanjutkan pendidikan ke jenjang S2, penghargaan guru berprestasi, kegiatan in house training, dan pemberian honor berdasarkan lama masa kerja dan jumlah jam mengajar. Sedangkan cara yang diimplementasikan untuk memuaskan pelanggan ekstern (orang tua peserta didik/wali murid) yang akan menyampaikan kritik, saran, atau pendapat, yaitu dengan menyediakan kotak saran, atau secara langsung dalam forum parenting. Juga dapat dengan menghubungi wali kelas atau kepada madrasah. Madrasah Imam (MI) Puro Sutoragan Kecamatan Kemiri Kabupaten Purworejo sangat berfokus kepada pelanggan mengingat biaya mempertahankan kepuasan pelanggan lebih murah daripada memprospek pelanggan baru. Dampak positif kepuasan pelanggan bagi lembaga pendidikan yaitu mengurangi biaya promosi, masyarakat dalam hal menyekolahkan putra putrinya cenderung lebih mengutamakan opini teman/keluarga dari iklan atau brosur; (3) Membangun loyalitas pelanggan. Cara yang diimplementasikan dalam membangun loyalitas pelanggan antara lain dengan menjalin hubungan baik terhadap pelanggan intern, Dewan Guru dan Siswa RA Masyithoh, Wali murid MI Imam Puro Sutoragan, Wali Murid RA Masyithoh, dan berbagai badan usaha; (4) mengintensifkan komunikasi dengan pelanggan. Cara yang diimplementasikan antara lain dengan komunikasi langsung melalui parenting, menyebarkan brosur, dan media sosial; dan (5) meningkatkan sarana prasarana pendidikan. Cara yang diimplementasikan dalam meningkatkan sarana prasarana pendidikan melalui pembangunan yang berkesinambungan, mulai tahun 2014 secara bertahap sampai dengan tahun 2019 sudah membangun menambah 4 buah ruang kelas, aula, rumah tahfidz, dua ruang kelas RA, lapangan olah raga, rumah konveksi, dan pengadaan mobil jemputan.

\section{c. Mengevaluasi strategi positioning}


Manajer pemasaran harus secara terus-menerus memantau pasar sasaran dan penawaran untuk menetapkan kapan penawaran baru harus diperkenalkan di pasar dan kapan harus memodifikasi penawaran yang ada atau kapan harus mengganti penawaran tersebut. ${ }^{32}$

Berdasarkan hasil penelitian, Madrasah Ibtidaiyah (MI) Imam Puro Sutoragan Kecamatan Kemiri Kabupaten Purworejo, sudah melakukan evaluasi strategi positioningnya. MI Imam Puro Sutoragan senantiasa meningkatkan layanan jasa pendidikan melalui program-progam unggulannya, yang dapat memikat hati pelanggan. Antara lain: pembiasaan karakter akhlak mulia, pembiasaan pengamalan yang berciri khas Islam Ahlussunah Wal Jamaah, kegiatan drumband, Kelas Insprirasi, program tahfidzul Qur'an, kegiatan POCIL, dan sekarang merintis boarding school. Kegiatan program unggulan tersebut secara intensif dipromosikan kepada masyarakat luas, dan berhasil memengaruhi orang tua peserta didik dan masyarakat luas. Hal ini terbukti dengan mengalirnya donatur dari berbagai lapisan masyarakat luas yang menginfaqkan dan mewakafkan harta bendanya untuk mendukung peningkatan sarana prasarana pendidikan di Madrasah Ibtidaiyah Imam Puro Sutoragan Kecamatan Kemiri Kabupaten Purworejo.

\section{KESIMPULAN}

Berdasarkan analisis data dan pembahasan yang sudah dilakukan, maka dapat ditarik kesimpulan sebagai berikut:

1. Segmentation Pemasaran Madrasah di Madrasah Ibtidaiyah (MI) Imam Puro Sutoragan Kecamatan Kemiri Kabupaten Purworejo

Kepala MI Imam Puro Sutoragan Kecamatan Kemiri Kabupaten Purworejo menentukan kebijakan segmentasi pasar berdasarkan segmentasi geografis, segmentasi demografis, dan segmentasi perilaku. Tujuan kegiatan segmentasi pasar MI Imam Puro Sutoragan Kecamatan Kemiri Kabupaten Purworejo antara lain: (a) Mengetahui karakteristik calon peserta didik; dan (b) Mengetahui keinginan dan kebutuhan (komitmen) orang tua calon peserta didik dalam menyekolahkan putra putrinya.

\footnotetext{
32 Kerin, Roger A. dan Peterson, Robert A., Op.Cit., hlm. 142.
} 
Prosedur kegiatan segmentasi pasar MI Imam Puro Sutoragan Kecamatan Kemiri Kabupaten Purworejo sebagai berikut: (a) Diawali dengan melakukan riset atau penelitian sederhana kepada orang tua calon peserta didik, sekolah dan madrasah yang berada di sekitarnya, dan MI Negeri Njenjeran Bantul yang lebih maju; (b) Menitindaklanjuti riset dengan kegiatan mengidentifikasi dan menganalisa terhadap karakteristik calon peserta didik, kebutuhan dan keinginan (komitmen) orang tua calon peserta didik dalam menyekolahkan putra putrinya; (c) memberi nama berdasar karakteristik yang dominan, yaitu pendidikan calon peserta didik.

2. Targetting Pemasaran Madrasah di Madrasah Ibtidaiyah (MI) Imam Puro Sutoragan Kecamatan Kemiri Kabupaten Purworejo

Kepala MI Imam Puro Sutoragan Kecamatan Kemiri Kabupaten Purworejo dalam memilih segmen pasar yang akan menjadi fokus upaya pemasaran sebagai berikut: (a) Segmentasi geografi, Desa Sutoragan dan sekitarnya; (b) Segmentasi demografi yaitu agama, umur, dan pendidikan; (c) Segmentasi perilaku yaitu perilaku calon peserta didik dan perilaku orang tua calon peserta didik. Pemilihan segmen yang utama kepada calon peserta didik terhadap alumni RA Masyithoh karena RA Masyithoh Sutoragan sudah terintegrasi dengan MI Imam Puro Sutoragan. Sedangkan pemilihan segmen berikutnya terhadap calon peserta didik yang pendidikannya berasal dari selain RA Masyithoh Sutoragan yang bertujuan untuk mendapatkan informasi-informasi baru yang dapat memperluas wawasan, mengetahui produk seperti apa yang dibutuhkan masyarakat, dan sebagai alat promosi.

Kepala Madrasah Ibtidaiyah (MI) Imam Puro Sutoragan Kecamatan Kemiri Kabupaten Purworejo memutuskan strategi targetting yang akan digunakan dalam pemasaran madrasah adalah sebagai berikut: (a) kepada calon peserta didik RA Masyithoh Sutoragan dengan melakukan kegiatan bersama yang mengikutsertakan MI Imam Puro Sutoragan dan RA Masyithoh Sutoragan, baik siswa, guru, dan wali murid; (b) kepada calon peserta didik selain RA Masyithoh Sutoragan, meliputi aktif dalam kegiatan sosial, menyebar brosur, up date status di media sosial, kerja sama dengan wartawan; dan informasi dari mulut ke mulut. Kelebihan strategi targetting MI Imam Puro Sutoragan adalah: (a) meningkatkan semangat kekeluargaan antara RA Masyithoh Sutoragan dengan MI Imam Puro Sutoragan baik peserta didik, 
dewan guru, dan wali murid; (b) Media cetak dan elektronik dapat menjangkau masyarakat luas; dan (c) Informasi dari mulut ke mulut, gratis tanpa biaya.

Pelaksanakan strategi targetting pemasaran madrasah di MI Imam puro Sutoragan Kecamatan Kemiri Kabupaten Purworejo dilakukan oleh Kepala Madrasah, Ketua Yayasan, Komite, Dewan Guru, maupun wali murid. Pelaksanaan strategi targetting: (a) kepada peserta didik yang berasal dari RA Masyithoh Sutoragan, dengan mengadakan kegiatan bersama meliputi kegiatan bersama antara peserta didik MI Imam Puro Sutoragan dengan peserta didik RA Masyithoh Sutoragan, kegiatan bersama antara peserta didik dan wali murid baik RA Masyithoh Sutoragan maupun MI Imam Puro Sutoragan, dan menyediakan fasilitas bersama kepada RA Masyithoh berupa mobil jemputan, aula, dan lapangan olah raga. Kegiatan ini bertujuan agar peserta didik RA Masyithoh merasa senang kepada MI Imam Puro Sutoragan, dan orang tuanya termotivasi melanjutkan belajar putra putrinya di MI Imam Puro Sutoragan Kecamatan Kemiri Kabupaten Purworejo; (b) pelaksanaan strategi targetting kepada peserta didik selain RA Masyithoh Sutoragan meliputi berpartisipasi aktif dalam kegiatan sosial masyarakat berupa silaturahim dalam keadaan suka maupun duka, pemberian santunan, pengajian, dan sebagainya; menyebar brosur kegiatan Penerimaan Peserta Didik Baru menjelang Tahun Pelajaran Baru; up date status secara intensif pada setiap even kegiatan melalui media sosial; bekerja sama dengan wartawan untuk meliput kegiatan, sehingga informasi kegiatan dapat dimuat pada media cetak maupun elektronik, yang selanjutnya dapat dikonsumsi oleh masyarakat, dan informasi tersebut semakin tersebar luas dari mulut ke mulut.

3. Positioning Pemasaran Madrasah di Madrasah Ibtidaiyah (MI) Imam Puro Sutoragan Kecamatan Kemiri Kabupaten Purworejo

MI Imam Puro Sutoragan Kecamatan Kemiri Kabupaten Purworejo menentukan positioning sebagai berikut: (a) menawarkan diferensiasi layanan jasa pendidikan, (b) menciptakan kepuasan pelanggan, (c) membangun kepuasan pelanggan, (d) mengintensifkan komunikasi dengan pelanggan, dan (e) meningkatkan sarana prasarana pendidikan. Berbagai program strategis tersebut untuk mencetak lulusan sesuai visi madrasah yaitu "Terwujudnya Peserta Didik 
Yang Bertaqwa, Santun, Maju, dan Qur'ani”, yang dinyatakan dengan kata "BERSAMA QU"

MI Imam Puro Sutoragan Kecamatan Kemiri Kabupaten Purworejo dalam mengimplementasikan strategi positioning yang pertama dengan menawarkan diferensiasi layanan jasa pendidikan dalam bentuk: (a) seragam dan atribut Lembaga Pendidikan Ma'arif Nahdlotul Ulama; (b) pembiasaan pengamalan Islman berciri khas Ahlussunah Wal Jamaah; (c) pembiasaan karakter akhlak mulia; 4)memberi penghargaan kepada siswa berprestasi; menyelenggarakan kegiatan ekstrakurikuler; dan keunggulan biaya. Implementasi strategi positioning pemasaran madrasah yang kedua yaitu: menciptakan kepuasan pelanggan intern dan ekstern. Kepada pelanggan intern berupa meninggatkan profesionalisme dan kesejahteraan guru, sedang kepada pelanggan ekstern berupa menyediakan wadah kritik atau saran berupa kotak saran, parenting, atau secara langsung menyampaikan kritik atau kepada Kepala Madrasah atau wali kelas. Implementasi strategi positioning pemasaran madrasah yang ketiga yaitu membangun loyalitas pelanggan. Membangun loyalitas pelanggan yang dilakukan dengan cara: (a) menjalin hubungan yang baik kepada dewan guru, karyawan, peserta didik MI Imam Puro Sutoragan dan RA Masyithoh Sutoragan, wali murid MI Imam Puro Sutoragan dan RA Masyithoh Sutoragan; (b) masyarakat lingkungan sekitar; (c) pondok pesantren wilayah sekitar; (d) badan usaha; dan (e) lembaga terkait. Implementasi strategi positioning pemasaran madrasah yang keempat yaitu dengan melakukan komunikasi kepada pelanggan secara langsung face to face, menyebar brosur, dan media sosial. Implementasi strategi positioning pemasaran madrasah yang kelima dengan meningkatkan sarana prasarana pendidikan, yang berupa penambahan ruang kelas baru, ruang aula, rumah tahfidz, ruang kelas RA Masyithoh, lapangan olah raga, rumah usaha konveksi, mobil jemputan, dan asrama boarding school.

Strategi positioning pemasaran Madrasah Ibtidaiyah Imam Puro Sutoragan dapat diterima dengan baik di benak pelanggan. Terbukti dengan meningkatnya jumlah siswa dari tahun ke tahun yang berasal dari berbagai wilayah, dan antusiasnya berbagai lapisan masyarakat berpartisipasi dengan menitipkan infaq untuk kelancaran kegiatan belajar mengajar dan pembangunan sarana prasarana pendidikan. Madrasah Ibtidaiyah Imam Puro Sutoragan Kecaman Kemiri Kabupaten 
Purworejo selalu berorientasi kepada kepuasan pelanggan, membangun loyalitas pelanggan dengan berbagai strategi positioning yang unik, kreatif, dan mengikuti perkembangan jaman.

\section{DAFTAR PUSTAKA}

Alma, Buchari. (2016). Manajemen Pemasaran dan Pemasaran Jasa. Bandung: Alfabeta

Arikunto, Suharsimi dan Yuliana, Lia. (2012). Manajemen Pendidikan. Yogyakarta: Aditya Media bekerja sama dengan FIP UNY.

Assauri, Sofjan. (2017). Manajemen Pemasaran, Dasar, Konsep dan Strategi. Jakarta: Raja Grafindo Persada.

Cannon, Joseph P., et al. (2008). Pemasaran Dasar, Edisi 16 Pendekatan Manajerial Global Buku 1. Jakarta: Salemba Empat.

Eliyanto. (2018). Manajemen \& Kepemimpinan Pendidikan Islam. Kebumen: Institut Agama Islam Nahdlatul Ulama (IAINU).

Farikhah, Siti. (2015). Manajemen Lembaga Pendidikan. Yogyakarta: Aswaja Presindo.

Jahari, Jaja dan Syarbini, Amirulloh Syarbini. (2013). Manajemen Madrasah Teori, Strategi dan Implementasi. Bandung: Alfabeta.

Kerin, Roger A. dan Peterson, Robert A. (2015). Pemasaran Strategis, Kasus dan Komentar Edisi Bahasa Indonesia. Jakarta: PT Indeks Permata Putri Media.

Kotler, Philip. (2002). Manajemen Pemasaran Edisi Milenium 1. Jakarta: Prenhallindo.

Laksana, Fajar. (2008). Manajemen Pemasaran Pendekatan Praktis. Yogyakarta: Graha Ilmu.

Lumpioadi, Rambat. (2013). Manajemen Pemasaran Jasa Berbasis Kompetensi. Jakarta: Salemba Empat.

Machali, Imam dan Hidayat, Ara. (2016). The Hand Book Of Education Management, Teori dan Praktik Pengelolaan Sekolah/ Madrasah di Indonesia. Jakarta: Prenadamedia Group.

Muhaimin et al, (2015). Manajemen Pendidikan Aplikasi dalam Penyusunan Rencana Pengembangan Sekolah/Madrasah. Jakarta: Prenadamedia Group.

Patton, Michael Quinn, (2006), Metode Evaluasi Kualitatif, Yogyakarta: Pustaka Pelajar.

Rangkuti, Freddy. (2017). Teknik Membedah Kasus Bisnis Analisis Swot. Jakarta: Gramedia Pustaka Utama.

Sugiyono, 2009, Metode Penelitian Pendidikan, Bandung: Alfabeta.

Tjiptono, Fandy. (2008). Strategi Pemasaran Edisi III. Yogyakarta: Andi Offset. . (2015). Strategi Pemasaran, Promosi, Iklan, Media Sosial, Kompetitif Market, Distribusi, Pelanggan, Pasar, Branding, Produk, Harga Edisi - 4. Yogyakarta: Andi Offset. 
Wijaya, David. (2016). Pemasaran Jasa Pendidikan. Jakarta: Bumi Aksara. 